\title{
The Role of Semarang City Wage Board in Protecting the Workers/ Laborers
}

\author{
Triani Fatika Hasri ${ }^{1 *}$, Sonhaji ${ }^{2}$, Suhartoyo ${ }^{3}$ \\ \{fathikahasry5@gmail.com*1, sonhajimuh19@gmail.com²
}

Fakultas Hukum, Universitas Diponegoro, Jl. Prof. H. Soedarto, S.H., Semarang, Indonesia 50275 1,2,3

\begin{abstract}
Humans always try to meet all their needs, both for their own needs and their family. Every person has their own different needs. It depends on the ability or the purchasing power of each individual. Purchasing power depends on earnings (wages) obtained after working for period of times. To provide protection on wages, the government established the Wage Council, (National, Provincial and District/Municipal) which is a non-structural tripartite institution. By the establishment of the Minimum Wages Council Wage, it is expected that wages received by workers/labors, can be a sufficient source of income to meet the needs of workers/laborers and their families in a good way. Psychologically, wages can create satisfaction for workers/laborers.
\end{abstract}

Keywords: Wage Council, labor/wage protection, Semarang City

\section{Introduction}

Labor issues in Indonesia are very complex national problems. The main problem in employment is the issue of employment. So far, the government views labor issues only on the labor force that is increasingly booming, and matters relating to protection, as well as improvement of workers' welfare are neglected, including wage problems faced by workers/laborers which are deemed unable to be handled and resolved. A dualistic labor market situation with excess supply of labor, and an imbalance in the growth of the available workforce. On the other hand, the low quality of the workforce causes wages to become an unresolved issue, and has always been the main discussion in the field of employment.

Workers/laborers who feel less satisfied with wages provided by employers where they work will lead to a complex problem when they think it is not accordance with the level of jobs they spent for. The level of needs that are increasing and expensive, must be met with low wages, so there is no balance between the two. For workers/laborers, wages are the spear of war to support their families. On the other hand, for entrepreneurs wages are factors of production which are expenses that must be paid by the production process, so that it will determine the articles of association whether or not the profits are obtained.

Wages are an income in return from the employer to the work recipient for a job for services that have been or will be done. Wages serve as guarantees of a viable survival for humanity and production, expressed or valued in the form of money determined according to an agreement, the laws, and regulations. Thus, wages are the rights of workers or laborers who are accepted and expressed as compensation from employers or employers to workers or laborers who are determined and paid according to an employment agreement, agreement, or regulation. [1] 
Wage or payment of wages is one problem that has never been debated, both by workers/employers and employers/employers, and by the government. Likewise by many organizations, whatever the form of organization, whether private or government. It is as if remuneration is an inexhaustible job for each stakeholder, because each has an interest in accordance with their respective positions. The low wages will always lead to the conflict between management and the party employed. This is proven by the number of demonstrations or demonstrations in various regions in Indonesia. Worthiness of wages that are not in line with expectations, not balanced with what they do.

Wages are one of the most sensitive aspects of work relations. Various parties concerned see wages from different sides. Workers/laborers see wages as a source of income to meet the living needs of workers/laborers and their families. Psychologically wages can also create satisfaction for workers/laborers. On the other hand, employers see wages as one of the costs of production. The government sees wages, on the one hand as being able to guarantee the fulfillment of decent needs for workers and their families, given the productivity of workers/laborers, and increasing the purchasing power of the people. [2]

Minimum wages are set in order to maintain harmonious industrial relations between employers and workers/laborers with support from the government. Minimum wages are aimed at improving the welfare of workers/laborers and also ensuring the sustainability of the business world. The importance of the participation of both employers and workers/laborers in planning minimum wages is to reach an agreement on consensus on the fair amount of wages for both parties. Planning carried out if it involves the community or stakeholders directly will be able to avoid potential conflicts in the implementation of development, especially regional economic development. The wage policy is mandated by Law No. 13 of 2003 concerning Manpower wherein in its implementation the regional government together with the stakeholders involved try to set the minimum wage level. [3] With the involvement of all related parties, wage issues can be addressed and resolved amicably and deliberately by way of resolution. Fair minimum wages will bring investment into the regions which will support the implementation of development in the regions. From the incoming investment, new jobs will be opened that can absorb labor so that it will be in line with the national development goal of achieving people's welfare.

"Basically, the right of workers/laborers to wages arises when there is an employment relationship between workers/laborers and employers and ends when the employment relationship is terminated. Thus, workers who are subject to suspension by employers are still entitled to receive wages because they have not yet received a decision from an industrial relations dispute resolution agency with permanent legal force. In addition, to the above provisions, Article 93 paragraph (1) juncto paragraph (2) letter f of the Manpower Act also regulates that in essence employers are still obliged to pay the wages of workers/laborers who are willing to do the work promised but the employer does not employ them, either because of an error themselves or obstacles that entrepreneurs should be able to avoid." [4]

The purpose of the government to regulate wages and wages for workers/laborers is to protect workers/laborers from employer/employer abuse in providing wages. Every worker/laborer has the right to earn income that meets a decent living for humanity. The worker/laborer receives wages from the employer and is protected by law. The role of the government in this case is to set a wage policy that protects workers/laborers so that they can meet the living needs of workers/laborers and their families. 
The stipulation of wages in every province in Indonesia always causes problems. Viewed from the employers, it consider the stipulated wages burdensome to the business world, and on the labor/labor side considers the government is still not in favor of the interests of the workers/laborers. One of the government's responsibilities to the community is to determine and set minimum wages for workers/laborers. The basis used is Law No. 13 of 2003 concerning Employment. The minimum wage is a net social safety net that is recognized as a high cost borne by employers. [5] It is certain and proven that employers or companies look for opportunities so that the wages paid do not cause production activities to be disrupted and cause other losses.

Wages are defined as provisions issued by the government regarding the obligation of companies to pay wages at least equal to the needs of decent living (KHL) to the lowest level of workers/laborers. In other words, that the minimum wage can be said to be one of the government's policy instruments to protect the lowest-tier workers/laborers in every company so that they get the lowest wages according to the value or price of a decent living necessity.

The phenomenon that occurs in society is the frequent demonstrations demanding wage increases on labor day commemoration. On the other hand, employers who feel that the demands of workers/laborers or the minimum wage set are heavy to be implemented. The consequence is bringing investment owned out of one area. The debate about the district/city minimum wage (UMK) often results in demonstrations conducted by workers/laborers. Repeated demonstrations on the same issue clearly show the issue of wages. Three parties involved in this problem, namely the government, employers, workers/laborers, seem to see this problem from a different perspective so it is difficult to find common ground. Workers see with the lens of fulfilling the needs of a decent life, employers see with the lens of the cost of workers/laborers, while the government sees with the lens of competitiveness to attract investment. [6]

The state of Indonesia, precisely in Central Java, has 33.774.141 people, including 16.435.142 people working and 863.783 people who are unemployed. Seen from these figures prove that there are still many residents in Central Java who are still unemployed, and this problem is still unresolved due to an imbalance between the field of workers and the population in Central Java which is classified as dense. However, it cannot be denied that workers/laborers have a high and comparable quality of education because there are also many workers who have only minimal education, for example Elementary School (SD) graduates, first or secondary level graduates.

This situation raises the tendency of employers to act arbitrarily to their workers/laborers. Labor is seen as an object. Workers are considered as external factors that have the same status as supplier customers or buyer customers who function to support the continuity of the company and not internal factors as an inseparable part or as a constitutive element that makes the company. Employers can freely pressure their workers to work optimally, sometimes exceeding their work abilities. For example, employers can set a maximum wage as much as the provincial minimum wage, regardless of the work period of the worker. The minimum wage concept that has been applied so far has not succeeded in creating industrial relations as expected. [7]

Existing wage dilemmas, both from sociological and juridical aspects, should not be allowed to continue. Therefore, a solution needs to be discovered so that the interests of workers/employers with employers in conflicting wages can be minimized. If the wage dilemma is allowed to continue it will result in non-conducive industrial relations in Indonesia, and not achieving the goals of employment development and national development goals. 
Three mechanisms in setting minimum wages are collective bargaining, consultation, and government legislated Collective bargaining. Wages are determined based on the existence of a collective offer made between employers and workers/laborers directly. [8] The government only determines the outcome of the agreement. Consultation approach in which the government only positions itself as a legislator or guarantor in existing laws and laws. And another option is government legislated where the government sets the minimum wage level directly without paying attention or listening to proposals from employers or workers/laborers.

Before setting a minimum wage policy, the government makes a wage plan that is able to produce a fair wage for stakeholders in it. Planning according to Friedman is an attempt to bridge scientific knowledge with techniques (scientific and technical knowledge) to actions in the public domain Planning that pays attention to community participation and the business world is the basic principles of good governance. [9] The government is required to be able to interact and coordinate in a healthy and harmonious manner with the power of the community (civil society) and the private sector as a consequence of exercising political, economic and administrative authority to regulate development matters. [10] On the other hand, full participation involving regional development actors starting from the planning, implementation and monitoring and evaluation stages of development is the driving force for realizing an integrated regional development management system towards increasing community welfare and welfare. [11] Good planning must be able to reflect the basic principles of good governance.

In this regard, in order to create a more realistic minimum wage setting, the determination of the minimum wage is carried out by considering the improvement of the welfare of workers without ignoring the productivity and progress of the company and the development of the regional economy in general. To improve the welfare of workers/laborers in Indonesia it is necessary to increase wages for employees as a whole in order to avoid social inequalities between people. If someone's needs are met properly, the economy in the community is developing well.

The minimum wage policy implemented is general and applicable in an area without distinguishing the ability of the sectoral company. In practice, the provision of city minimum wages has not been able to accommodate companies in sectors that are able to pay higher wages, so as to slow the increase in welfare.

The wage council is a manifestation of the interests of the nation and the provinces to encourage agreements in determining the direction of (one of the factors) economic growth. The only function that appears from the wage council is to give advice and considerations specifically for wages for workers/laborers.

Several articles which regulate minimum wages, are affirmed in Article 97 of Law Number 13 of 2003 concerning Manpower emphasizing that the provisions regarding decent income, wage policy, decent living necessities, are regulated by government regulations. In addition to wage regulations regulated in the form of laws, the government also makes implementing regulations, both in the form of Government Regulations, Ministerial Decrees, and in the form of relevant Ministerial Regulations. The government regulation issued is Government Regulation Number 78 of 2015 concerning wages, but many parties consider the regulation not in line with the mandate of Law Number 13 of 203 Regarding Employment. With the existence of Government Regulation Number 78 of 2015, the basic rights of workers/laborers are reduced and are in conflict with decent wages, living costs and social security.

The city of Semarang is the capital of Central Java Province located in Indonesia. The Semarang City's economy according to BPS 2012 data is dominated by the industrial sector 
and the trade. The Gross Regional Domestic Product (GRDP) of 2012 so that the city of Semarang is dubbed as an Industrial City that has a lot of labor. The city of Semarang has a tripartite cooperation institution so that it can be said that the Semarang City Wage Board is a derivative of the tripartite cooperation institution, where one of the duties and functions of the wage council provides advice and consideration in setting minimum wages in the City of Semarang.

Based on the description above, the identification and formulation of the main issues is as follows:

1. What is the government's authority in terms of setting minimum wages for workers/laborers?

2. What is the position and role of the wage council in setting minimum wages as legal protection for workers/laborers in Semarang city?

\section{Method}

This research uses an empirical juridical approach. The method of analyzing the results of this study uses descriptive analytics... Scientific activities include activities: verification, comparison with various sources and research informants related to the research topic.

\section{Results and Discussion}

\subsection{Overview of Wage Councils}

Wage Council is a non-structural institution that is tripartite in nature, whose membership consists of elements of government, organizations, employers and trade unions and experts (academics). [12] In order to support the Governor's policy, especially in terms of Wages. Each region has its own structure and organization for the Wage Council, including in the City of Semarang. The Semarang City Wage Board was formed by the Decree of the Mayor of Semarang Number 561.1/98 of 2018 concerning the Establishment of the Semarang City Wage Board in 2018-2021. The purpose of establishing the Semarang City Wage Council is to help, monitor, and participate in recommending the Semarang City minimum wage amount to be submitted to the Mayor, and eventually will be determined by the Governor. [13]

In addition to those stipulated in Presidential Decree No. 107/2004, the Regency/City Wage Board can form a task force in the commission and further regulate its work procedures. Candidates for wage council members from trade union or trade union elements who meet the tripartite representation requirements. Unions/laborers that have been registered in accordance with applicable laws and regulations, can nominate their representatives to sit in institutional industrial tripartite relations after having at least 10 (ten) work units or at least 2,500 members at the Regency/City level.

According to article 98 of Law Number 13 of 2003 concerning Manpower, the membership of the National level wage council is appointed and terminated by the President, while the Provincial level membership is appointed and terminated by the Governor, and the Regency/City level membership is appointed and terminated by the Regent/Mayor. 


\subsection{Government Authority in Setting Wages for Workers/Laborers}

Wage or payment of wages is one problem that always has been debated, both by workers/employers and employers/employers and by the government. Likewise by many organizations, whatever the form of organization, be it private or government. It is an endless work for every stakeholder, because each has an interest in accordance with their respective positions. Low wages or wages also always lead to conflict between management and the people employed. This is evidenced by the many demonstrations/demonstrations in various regions in Indonesia. Worthiness of wages that are not in line with expectations, not balanced with what they do.

Of the different interests regarding wages, strict understanding, systems and arrangements are needed. To obtain the same unity of understanding and interpretation, especially for workers/laborers and employers. In accordance with the mandate of the 1945 Constitution Article 27 Paragraph (2) "Every citizen has the right to work and a decent living for humanity" for that wages paid to workers/laborers, they must be able to fulfill a decent life. So that the income of workers/laborers can be met physical, non-physical and social needs which include food, drinks, clothing, housing, education, health, old age insurance, and recreation funds. In addition, the objective of wage policy is expected to be able to encourage economic growth and expansion of employment opportunities, as well as improve the welfare of workers/laborers and their families.

The government has authority for remuneration in Indonesia, especially in protecting workers/laborers from receiving low wages. In terms of making regulations in the area of wages in order to guarantee the necessities of a decent life for workers/laborers throughout Indonesia and their families. In an effort to provide protection to lower-level workers, so that their wages do not decline, the government intervenes in wage issues through setting minimum wages. The role of the government is also inseparable from the Wage Council because it includes, in an effort to recommend minimum wage rates, in practice there has never been a deal because each has its own proposed number, especially from the workers/laborers, so in order to protect workers/laborers it is of course The Wage Board proposes the highest number to the Mayor. Because for the employers, they have referred to the formula Government Regulation No. 78 of 2015 concerning Wages. [13]

Government policies in the area of wages are motivated by problems due to conflicts of interest between employers and workers/laborers which include low wages for workers/lower laborers, lowest and highest wage gaps, varying wage components, and unclear relationship between wages and productivity. The low wage for low-level workers is felt by workers, but it is very difficult to be detected by labor inspectors in the context of setting minimum wages. For formal workers, it may be easier to trace, however, for informal workers, it will be very difficult to be tracked unless there are reports coming from the community and workers or workers. [14] Although wage violations are often carried out by employers, Disnaker as an institution responsible for conducting surveillance and investigations does not take "judicial" actions such as investigations, investigations, and investigations. The reason for supervisors and investigators do not rely on the Disnaker is institutionally not supported by sufficient and capable human data sources, a broad scope of scope of duties plus inadequate legal instruments, and intervention of regional heads with political nuances and conspiracy of supervisors/investigators with employers. [15]

According to Jhon Rawis, the minimum wage stipulation from the government is compulsory, so employers will not give workers wages lower than the prevailing minimum wage. Unless, they get permission from the government in accordance with the principle of 
justice. [12] From this opinion, it implies the hope of support from all parties (workers/laborers and employers) so that the minimum wage provisions can be implemented as well as possible.

\subsection{Position and Participation of Wage Councils in Setting Minimum Wages}

In determining wages, the Regency/City Wage Council has special authority. Referring to Permenkertans Number 12 of 2012 concerning Components and Implementation of the Achievement of the Need for a Decent Life that lists things that can be done by the Wage Board. The City Wage Council can be included as a policy network at the local or regional level. As a local institution where members joined in it are local community groups, the function of local institutions according to Mubyarto revealed by Muwardi, namely: [16]

1. Being a place of communication between the government, the community, and also between community groups.

2. Being a forum for participation in supporting government programs.

3. Being a means to improve community skills, can be in the form of abilities and knowledge.

4. Being a means to change people's thinking patterns.

5. Being a means to improve community welfare.

Additionally, Mawardi quoted Cheema's opinion, the roles of a local institution or institution include:

1. Introducing participation,

2. Arranging and determining local goals

3. Simplifying service provisions.

4. Mobilizing local resources.

5. Developing communication.

6. Supporting program various local needs and guidance.

The activity of setting minimum wages in the City of Semarang is determined by the Governor but based on a proposal given by the Semarang City wage council. [17]

The role is more likely or closer to the contribution or share associated with the duties and functions of a human being. The purpose of the role is to be able to carry out the tasks and functions attached to individuals or groups. To be able to achieve the role as desired, there is an effort to realize that role which is carried out clearly in the community in the form of direct participation in an activity. Law Number 13 of 2003 concerning Manpower states that tripartite cooperation institutions are a forum for communication, consultation and deliberation on labor issues. Tripartite cooperation institutions provide considerations, suggestions and opinions to the government in formulating policies and solving labor problems. The Regency/City Wage Board is a part of a tripartite cooperation institution that discusses the determination of the amount of wages that will be a reference for the Semarang City minimum wage which is later recommended to the Regent or Mayor to be submitted and determined by the Governor.

In setting the Semarang City Minimum Wage, the wage council is obliged to summon the parties involved such as the labor union. Trade unions in the city of Semarang to represent the interests of workers in institutions or tripartite institutions such as the city wage council, if the union is registered with the Department of Labor. The fact is not so that among groups of workers in the city of Semarang can not unite their aspirations in the process of bargaining with employers. Each element has its own opinion, but in the end must reach an agreement, 
namely from the Wage Council. The agreement from the Wage Board proposes 1 (one) number for recommendations so that in order to protect the workers/laborers the wage council provides the best recommendations in accordance with applicable regulations. [18] The entrepreneur is represented by the Indonesian Employers' Association (APINDO). This condition is beneficial for entrepreneurs because it will be good if only one voice is raised so that it does not result in a prolonged debate.

In implementing the City Minimum Wage determination, it is intended as a safety net between workers and employers. However, in practice, the implementation of MSEs that are normative in nature is often violated by employers in a variety of ways. There are still many employers who provide wages of only up to $75 \%$ of the amount of the minimum wage set by the government.. In connection with this, the supervisory function carried out by the local government concerns the wage council agency which is secretariat in the labor service becomes very important. The facts show that often large and financially strong companies make MSEs the standard wage in the company and there is usually an additional salary if the employees in the company are classified as senior. The reality that occurs in the field, many companies consider that MSEs are only as basic wages and already feel safe for workers/laborers who have 0-1 years of service, but there are still many companies that are still complaining with the specified amount of workers/workers who have $0-1$ years of service, so it is very important to have a structure and wage scale. [18] It is different with small companies or Micro Small and Medium Enterprises (MSMEs) who pay their employees below the UMK standard, this is a problem for small entrepreneurs who have little capital and financial instability.

Wage increases in companies tend to await the increase in MSEs set by the government, as a result workers/laborers' wages tend to be relatively fixed and less to live because prices of basic commodities continue to rise. Although large companies usually set their standard salaries above the MSE, the increase is due to demands and encouragement from workers to increase wages together with minimum wage increases. If there is something mentioned above, the workers/laborers usually protest the government as a neutral party. This is very contrary to the principle of employers who expect to spend a little money with maximum results, another case with workers/laborers who want wages to continue to rise and never enough for their daily needs. It is here that the Semarang City Wage Council acts as an intermediary or cushion to resolve conflicts between employers and workers/laborers that are never finished.

Payaman Simanjuntak stated that the minimum wage can be seen from two sides: First, as a protection for workers so that the value of wages received does not decline. The workers need a certain level of income to meet their needs and their families. Second, as a means of protection for employers in the sense that companies can succeed if supported by productive workers, one of the factors that influence worker productivity is the guarantee of meeting workers' needs. [5]

The Minimum Wage Determination in Semarang City has not $100 \%$ (one hundred percent) taken into account the matters mentioned above, usually the minimum wage determination made by the Semarang City Wage Board is only based on the Decent Living Needs (KHL). Based on Government Regulation Number 78 of 2015 Article 43 paragraph (1), the determination of the minimum wage as referred to in article 41 is carried out every year based on the necessities of a decent living by paying attention to productivity and economic growth. Paragraph (2) The need for a decent life as referred to in paragraph (1) is a standard requirement for a single worker/laborer to be able to live physically fit for the needs of 1 (one) month. Paragraph (3) The necessities of a decent life as referred to in paragraph (2) consist of 
several components. Paragraph (4) components as referred to in paragraph (3) consist of several types of living needs. Paragraph (5) components as referred to in paragraph (3) and types of living needs as referred to in paragraph (4) are reviewed within 5 (five) years. Paragraph (6) A review of the components and types of needs referred to in paragraph (5) is carried out by the Minister with consideration of the results of the study conducted by the National Wage Council. Paragraph (7) The study conducted by the National Wage Council as referred to in paragraph (6) uses data and information sourced from the authorized agency in the field of statistics. Paragraph (8) the results of a review of the components and types of necessities of life as referred to in paragraph (6) form the basis for the calculation of the minimum wage, taking into account the productivity and economic growth.

There are strict sanctions for employers who pay workers' wages less than the minimum wage that has been mutually agreed upon. In accordance with Law No. 13 of 2003 concerning Labor Article 90 paragraph 1, employers who pay their workers less than the minimum wage in the city where the company itself is, are liable to a maximum sentence of 4 (four) years in prison and a maximum fine of 400 (four hundred) million rupiah.

If the Semarang City Minimum Wage (UMK) is not agreed upon by employers and workers, the wage council is authorized to vote on the results of the wage council survey so as to minimize the debate between the employer and his workers. The voting process is carried out by inviting business representatives (APINDO), trade unions and wage councils plus experts. By generating a city minimum wage that is not far from the results of a survey conducted by the Semarang City Wage Board.

\section{Conclusion}

Wage protection through the Government's policy on Minimum Wages is still needed as a safety net for worker/labor protection. It is an anticipatory step, and therefore, the wages must be paid in accordance with the applied Minimum Wage standard. The role of the government in wages management is considered to be in maximal capacity with their regulations governing wages and strict sanctions in protecting workers/laborers.

Semarang City Wage Council has been able to accommodate all proposals from the elements incorporated in it, and has been able to capture information and become one discussion table between the government, employers and workers/laborers through each representative appointed to reach an agreement. The wage has also been able to mobilize human resources, funds and thoughts to achieve common goals, namely fair wages in order to realize harmonious industrial relations. The Semarang City Wages Board has been able to play a good role in formulating and providing alternative recommendations to the Mayor based on the discussion made with the related parties.

The Semarang City Wage Board does not have the authority to set the Minimum Wage amount, instead, to propose the wage numbers to the mayor and the governor, In principle, the determination of the Minimum Wage is the authority of the Governor on the basis of proposals from the Provincial Wage Board and/or Regent/Mayor.

\section{References}

[1] Maulanaihsan49.blogspot.com, "Upah dan Tenaga Kerja, Teori Upah dalam 
Perspektif Ekonomi Islam, Analisis UMR di Indonesia," 18 Dec 2013. [Online]. Available: http://maulanaihsan49.blogspot.com/2013/12/vbehaviorurldefaultvmlo.html. [Accessed: 07-Jul-2018].

[2] Government Regulation Number 78 of 2015 concerning Wages. .

[3] "Law Number 13 of 2003 concerning Manpower."

[4] T. J. A. Pramesti, "Bolehkah Memotong Upah Pekerja yang di-Skorsing? Hukum Online," $13 \quad$ Apr $2017 . \quad$ [Online]. Available: http://www.hukumonline.com/klinik/detail/lt51480c37790ca/bolehkah-memotongupah-pekerja-yang-di-skorsing.

[5] P. J. Simanjuntak, Teori dan sistem pengupahan. Jakarta: Himpunan Pembina Sumberdaya Manusia Indonesia (HIPSMI), 1996.

[6] Akatiga.org, "No Title." [Online]. Available: http://akatiga.org/index.php/artikeldanopini/perburuhan/138-upahburuhadayasaing. [Accessed: 21-Jul-2018].

[7] S. Suhartoyo, "Penguatan Organisasi Buruh/Pekerja Sebagai Sarana Perlindungan Buruh," Adm. Law Gov. J., vol. 1, no. 4, pp. 350-362, 2018.

[8] T. Boeri, Setting the minimum wages. Bonn: : IZA, Institute for the Study Labor, 2009.

[9] H. A. Rahman, "Keterlibatan Stakeholder dalam Perumusan Kebijakan Perencanaan Kota Bima," Universitas Brawijaya, 2009.

[10] C. Nasirin, and Alamsyah, Pemberdayaan Masyarakat dalam Perspektif Good Governance. Malang: Indo Press, 2010.

[11] A. Lubis, "Upaya meningkatkan partisipasi masyarakat dalam pembangunan," $J$. Tabularasa, vol. 6, no. 2, pp. 181-190, 2009.

[12] B. Setiadji, Upah Antar Industri Indonesia. Surakarta: Muhammadiyah University Press, 2002.

[13] Interview with H. Sonhaji, SH., MH., Semarang City Wage Board Deputy Chairman on October 11, 2018 at the Semarang Manpower and Transmigration Office. .

[14] W. Suyandono, Asas-Asas Hukum Perburuhan. Jakarta: Raja Grafindo Persada, 2014.

[15] I. Fahrojih, Hukum Perburuhan. Jakarta: Setara Press, 2016.

[16] and S. Mawardi, A., Suryono, A., "Peran Institusi Lokal dalam Menanggulangi Kemiskinan di Perkotaan," Wacana J. Sos. dan Hum., vol. 12, no. 1, 2009.

[17] Interview with Sri Rejeki, SP., Semarang City Wage Board Member on September 17 at the Semarang Manpower and Transmigration Office. .

[18] Interview with Dra. Ernie Triesniawaty, MH., Semarang City Wage Board Member on September 18, 2018 at the Semarang Manpower and Transmigration Office. . 